Jeffrey L. Apfelbaum MD, Leslie M. Shaw PH D, Jeffrey B. Gross MD, Craig B. Caldwell MD, Barry C. Spaulding MD

\title{
Modification of lidocaine protein binding with $\mathrm{CO}_{2}$
}

rather than decrease lidocaine toxicity. ${ }^{4}$ Clearly,

Using new, specially designed ultrafiltration devices and an enzyme immunoassay technique, the authors determined the effect of carbon dioxide tension on the fractional binding of lidocaine to human plasma proteins. Identical samples of serum at therapeutic $\left(2.2 \mu \mathrm{g} \cdot \mathrm{ml}^{-1}\right)$ and toxic $\left(6.8 \mu \mathrm{g} \cdot \mathrm{ml}^{-1}\right)$ lidocaine concentrations were tonometered at $37^{\circ} \mathrm{C}$ to $\mathrm{CO}_{2}$ tensions between 0.13 and $10.7 \mathrm{kPa}(1.0$ to $80.5 \mathrm{mmHg})$. The fraction of unbound lidocaine increased linearly with increasing $\mathrm{pCO}_{2}(\mathrm{r}=$ $0.93, p<0.001)$. These changes help to explain the increased central nervous system toxicity of lidocaine associated with hypercarbia.

High serum lidocaine concentrations are associated with signs and symptoms of central nervous system (CNS) toxicity including tinnitus, anxiety, disorientation, lightheadedness, and, in extreme cases, temporary unconsciousness and grand-mal seizures. ' Because lidocaine is a weak base with a pKa of $7.86,{ }^{2}$ respiratory acidosis decreases that fraction of the total serum lidocaine which is non-ionized. Since only uncharged molecules are able to cross the blood-brain barrier, ${ }^{3}$ respiratory acidosis would be expected to decrease the CNS toxicity of lidocaine. However, Englesson demonstrated that high carbon dioxide tensions increase

\section{Key words}

ANAESTHETICS, LOCAL: lidocaine; CARBON DIOXIDE TOXICITY: local anaesthetics.

From the Departments of Anesthesiology and Pathology and Laboratory Medicine, University of Pennsylvania and Philadelphia Veterans Administration Medical Center, Philadelphia, Pennsylvania.

Address correspondence to: Dr. Jeffrey B. Gross, Department of Anesthesia (112), Veterans Administration Medical Center of Philadelphia, University and Woodland Avenues, Philadelphia, Pennsylvania 19104. changes in ionization cannot explain lidocaine's increased toxicity at elevated $\mathrm{CO}_{2}$ tensions. Routledge and coworkers have recently shown that even when $\mathrm{pH}$ is maintained constant at 7.40 , there is considerable interindividual and intraindividual variation in lidocaine protein binding; ${ }^{5}$ they further demonstrated that at most, 39 per cent of lidocaine in the plasma is unbound and therefore available to cross the intact blood-brain barrier. We designed this study to determine if changes in lidocaine protein binding occur with changes in $\mathrm{CO}_{2}$ tension and could therefore account for the increase in CNS toxicity observed in the presence of respiratory acidosis.

\section{Methods}

By venipuncture of healthy volunteers, we collected enough blood to yield $50 \mathrm{ml}$ of pooled human plasma. None of the subjects was taking medications known to be bound to plasma proteins. We placed the samples in salinized glass tubes containing heparin and centrifuged them at $1000 \times$ $\mathrm{g}$ for $10 \mathrm{~min}$. After dividing the plasma into two $25 \mathrm{ml}$ aliquots, we added sufficient lidocaine to yield concentrations of 2 and $7 \mu \mathrm{g} \cdot \mathrm{ml}^{-1}$ respectively. We then divided each aliquot into five samples which we placed in stoppered glass test tubes and warmed to $37^{\circ} \mathrm{C}$. We kept the test tubes upright at all times to avoid interaction of plasma proteins with the rubber stoppers. With appropriate venting, we bubbled either $0,3,6,9$, or 12 per cent carbon dioxide in oxygen through each sample for $30 \mathrm{~min}$. After removing the needles from the stoppers, we took the tubes to a constant-temperature room which had been pre-heated to $37^{\circ} \mathrm{C}$. We anaerobically removed serum from the tubes and transferred duplicate samples to ultrafiltration devices (Syva, Palo Alto) which we had pre-filled with corresponding mixtures of carbon dioxide in oxygen. The ultrafiltration devices, in turn, were 
placed in $60 \mathrm{ml}$ capped glass bottles which were also filled with the appropriate gas mixtures. Centrifugation for $15 \mathrm{~min}$ at $5000 \times \mathrm{g}$ yielded a proteinfree ultrafiltrate for analysis.

We determined the lidocaine concentration of the ultrafiltrates as well as the original samples using the Emit-cad kit (Syva, Palo Alto). This immunoassay is optimally sensitive in the range of 1.0 to $12.0 \mu \mathrm{g} \cdot \mathrm{ml}^{-1}$ with a coefficient of variation of less than five per cent in our laboratory. The specificity of this assay has been investigated and the results have shown that neither of the major metabolities of lidocaine - monoethylglycine-xylidide and glycinexylidide - nor drugs likely to be given concurrently produce significant cross reactivity at therapeutic concentrations. ${ }^{6}$ Two studies have compared lidocaine values in patient's sera obtained by the Emit-cad ${ }^{\$}$ method with the corresponding values obtained by gas-liquid chromatography. Excellent agreement between the methods was found. ${ }^{7,8} \mathrm{~A}$ portion of each sample was analyzed for $\mathrm{PCO}_{2}$ with a Corning \#168 pH/Blood Gas Analyzer which was calibrated with standard gas mixtures before each determination.

To determine if there was significant binding of lidocaine to the filters themselves, we added lidocaine ( 2 and $7 \mu \mathrm{g} \cdot \mathrm{ml}^{-1}$ ) to aliquots of a proteinfree plasma filtrate. After allowing the samples to equilibrate with mixtures of carbon dioxide in oxygen, we repeated the ultrafiltration process (vide supra). We analyzed samples of this supernatant and filtrate using the immunoassay technique described above.

From the measured concentrations of lidocaine in the original plasma specimens and ultrafiltrate, we computed the fraction of unbound lidocaine in each sample. Using linear regression, we determined the relationship between the fraction of free lidocaine and carbon dioxide tension; we used a t-test to determine if the correlation coefficient differed significantly from zero. $\mathbf{P}<0.05$ indicated statistical significance.

\section{Results}

When lidocaine-containing $\left(2.3\right.$ and $\left.7.1 \mu \mathrm{g} \cdot \mathrm{ml}^{-1}\right)$ protein-free filtrates passed through the ultrafiltration devices, there was $91 \pm 2$ per cent (mean\pm SEM) recovery of lidocaine. Binding of lidocaine to the filters did not vary with carbon dioxide tension. We corrected our measurements of lido-

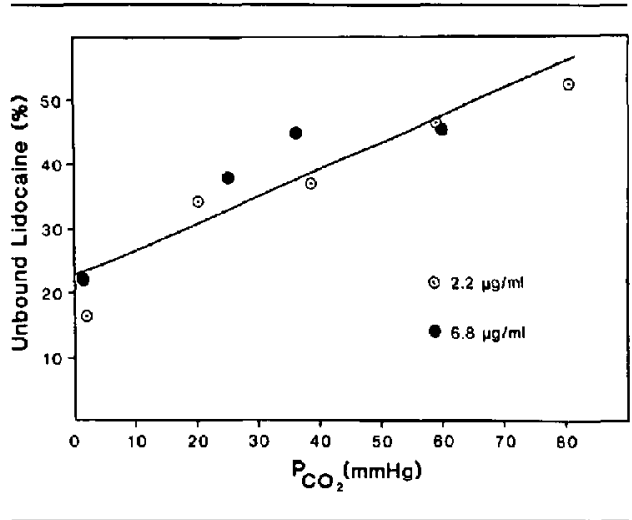

FIGURE Fraction of unbound lidocaine vs carbon dioxide tension at two lidocaine concentrations.

caine binding in the plasma samples (vide infra) to compensate for this nonspecific binding.

Total lidocaine concentrations of the wholeplasma lidocaine samples were 2.2 and $6.8 \mu \mathrm{g}$. $\mathrm{ml}^{-1}$. These values are within the therapeutic and preconvulsive ranges previously reported for lidocaine ${ }^{9,10}$ Measured carbon dioxide tensions ranged from $0.13-10.7 \mathrm{kPa}(1.0$ to $80.5 \mathrm{mmHg}$ ), while the associated unbound lidocaine fractions varied from 15 to 48 per cent. For technical reasons, data could not be obtained for one of the samples ( 12 per cent $\mathrm{CO}_{2}, 6.8 \mu \mathrm{g} \cdot \mathrm{ml}^{-1}$ lidocaine). The data obtained at the two lidocaine concentrations did not differ significantly (Figure); therefore, we pooled the data before performing the regression analysis.

Least squares linear regression demonstrated a strong positive correlation between plasma carbon dioxide tension and the fraction of unbound lidocaine $(r=0.93, p<0.001)$. The regression line has the equation: per cent unbound lidocaine $=22.97$ $+3.08 \times \mathrm{PCO}_{2}(\mathrm{kPa})$.

\section{Discussion}

The binding of drugs in plasma is intimately related to their pharmacokinetics and pharmacodynamics. Only that fraction of a drug which is unbound to plasma proteins is available to exert a pharmacological or toxic effect by binding to receptor sites. Additionally, macromolecule-bound compounds do not cross the intact blood-brain barrier. Lidocaine and other basic compounds have been shown to bind significantly to plasma $\alpha_{\mathfrak{l}}$-acid glycoprotein, an acute-phase reactant, whose concentration 
in plasma is extremely variable. Using equilibrium dialysis, Routledge and coworkers studied the binding of $\mathrm{C}^{14}$ lidocaine $\left(3 \mu \mathrm{g} \cdot \mathrm{ml}^{-1}\right)$ added to the plasma obtained from 24 healthy subjects; they found that the fraction of unbound lidocaine varied from 19.9 to 38.8 per cent at a $\mathrm{pH}$ of 7.40 and a temperature of $37^{\circ} \mathrm{C} .^{5}$ They also demonstrated an inverse relationship between the fraction of unbound lidocaine and the total plasma $\alpha_{3}$-acid glycoprotein concentration. This implies that lidocaine is, in fact, bound to $\alpha_{1}$-acid glycoprotein in human plasma. Conversely, these investigators found no relationship between lidocaine protein binding and plasma albumin concentration; therefore, albumin is not a significant binding protein for lidocaine in human plasma. Unfortunately, these investigators made no attempt to control the carbon dioxide tension of their samples; instead they adjusted the $\mathrm{pH}$ by adding a phosphate buffer. The nature and concentration of such a buffer may significantly affect plasma protein binding. "I

It is well established that plasma lidocaine concentrations in excess of $5 \mu \mathrm{g} \cdot \mathrm{ml}^{-1}$ may cause central nervous system toxicity. Symptoms of lidocaine toxicity include headache, dizziness, tinnitis, circumoral numbness, and chills. Objective signs include confusion, nystagmus, slurred speech and muscle tremors and culminate in seizure activity.' These clinical changes are associated with generalized slowing and increased amplitude of the EEG, with high-voltage spikes accompanying seizure activity. 12,13

In his classic study, Englesson demonstrated that in the intact cat, lidocaine's central nervous system toxicity is proportional to carbon dioxide tension: a given lidocaine concentration is more likely to cause toxicity in the presence of a respiratory acidosis. ${ }^{4}$ Previous attempts to explain this interdependance have concentrated on the effect of acid -base status on the ionization of lidocaine. ${ }^{14}$ Since lidocaine is a weak base, acidosis tends to decrease the fraction of lidocaine which is in the non-ionized form. Only non-ionized lidocaine can cross the intact blood-brain barrier; therefore, it was reasoned that respiratory acidosis should decrease the amount of lidocaine which enters the CNS. Clearly, this contradicts Englesson's findings.

In an attempt to resolve this paradox, Burney $e t$ al. ${ }^{15}$ used pressurized ( $50 \mathrm{psi}$ ) ultrafiltration devices at room temperature to determine the fraction of free lidocaine in plasma; they concluded that the fractional binding of lidocaine is inversely related to hydrogen ion concentration. However, these investigators failed to account for two limitations in their ultrafiltration technique: ${ }^{16}$ (1) ultrafiltration may be unreliable when performed with pressurization (Specter et al. ${ }^{17}$ reported variations of up to 97 per cent); (2) nonspecific binding of lidocaine to the membrane was not assessed independently. Additionally, ultrafiltration in the Bumey study was performed at $21^{\circ} \mathrm{C}$; temperature may markedly affect plasma protein binding. Finally, it is not clear in which samples the $\mathrm{pH}$ was adjusted by changes in $\mathrm{CO}_{2}$ tension as opposed to by the addition of sodium hydroxide or hydrochloric acid.

Our data, obtained at body temperature and corrected for nonspecific protein binding, help to explain Englesson's findings. Respiratory acidosis is associated with a significant increase in the fraction of lidocaine which is unbound to plasma proteins. Since only unbound lidocaine is able to cross the blood-brain barrier, ${ }^{18}$ respiratory acidosis increases the amount of lidocaine available to cause central nervous system toxicity. Conversely, hypocarbia increases lidocaine protein binding, thereby decreasing the amount of lidocaine available to cause CNS toxicity.

The results of the present study, using specially designed ultrafiltration devices at physiologic temperature, clearly demonstrate that significant changes in lidocaine protein binding occur with changes in $\mathrm{CO}_{2}$ tension. Moore ${ }^{19}$ emphasizes the importance of maintaining adequate ventilation in the face of impending local anaesthetic toxicity. One reason that this is important, of course, is to ensure adequate oxygenation of a patient whose oxygen consumption is increased by motor seizure activity. Our data suggest a second, possibly more important reason: by decreasing the fraction of unbound lidocaine available to cross the blood -brain barrier, early hyperventilation may actually prevent lidocaine-induced seizure activity.

\section{References}

1 Steen PA, Michenfelder JD. Neurotoxicity of anesthetics. Anesthesiology 1979; 50: 437-53.

2 Truant AP, Takman B. Differential physicalchemical and neuropharmacologic properties of local anaesthetic agents. Anesth Analg 1959; 38: 478-84.

3 Mayer SE, Melmon KL, Gilman AG. General prin- 
ciples. Chapter One In, Gilman AG, Goodman LS, Gilman A, (eds): The Pharmacological Basis of Therapeutics, 6th edition. New York, Macmillan, 1980 , p. 10.

4 Englesson $S$. The influence of acid-base changes on central nervous system toxicity of local anaesthetic agents I. Acta Anaesthesiol Scand 1974; 18: 79-87.

5 Routledge PA, Barchowsky A, Bjornsson TD, Kitchell $B B$, Shand $D G$. Lidocaine plasma protein binding. Clin Pharmacol Ther 1980; 27: 347-51.

6 Cobb ME, Buckley $N, H u M W$, Miller JG, Singh P, Schneider RS. Homogeneous enzyme immunoassay for lidocaine in serum. Clin Chem 1977; 23: 1161.

7 Pape BE, Whiting R, Parker KM, Mitra R. Enzyme immunoassay and gas-liquid chromatography compared for determination of lidocaine in serum. Clin Chem 1978; 24: 2020-2.

8 Jain S, Johnston A. The measurement of lidocaine at low concentrations in plasma, a comparison of gas-liquid chromatography with enyme immunoassay. Br J Clin Pharmacol 1979; 8: 598-9.

9 Gianelly $R$, von der Groeben J, Spivack A, Harrison $D$. Effect of lidocaine on ventricular arrhythmias in patients with coronary heart disease. N Engl J Med 1967; 277: 1215-9.

10 Jorfeldt L, Lofstrom B, Pernow B, Persson B, Warhen $J F$, Widman $B$. The effect of local anaesthetics on the central circulation and respiration in man and dog. Acta Anaesthesiol Scand 1968; 23: 153-69.

11 Shaw LM, Fields L, Mayock R. Factors influencing theophylline serum protein binding. Clin Pharmacol Ther 1982; 32: 490-6.

12 Seo N, Oshima E, Stevens J, Mori K. The tetraphasic action of lidocaine on CNS electrical activity and behavior in cats. Anesthetsiology 1982; 57: 451-7.

13 Wagman $I H$, deJong $R H$, Prince $D A$. Effects of lidocaine on spontaneous cortical and subcortical electrical activity. Arch Neurol 1968; 18: 227-90.

14 Englesson $S$, Grevsten $S$. The influence of acidbase changes on central nervous system toxicity of local anaesthetic agents II. Acta Anaesthesiol Scand 1974; 18: 88-103.

15 Burney RG, DiFazio CA, Foster JA. Effects of $\mathrm{pH}$ on protein binding of lidocaine. Anesth Analg 1978; 57: $478-80$.

16 Whitlam JB, Brown $K F$. Ultrafiltration in serum protein binding determinations. J Pharm Sci 1981; 70: $146-50$.

17 Spector $R$, Vernick $R$, Lorenzo AV. Effects of pressure on the plasma binding of digoxin and ouabain in an ultrafiltration apparatus. Biochem Pharmacol 1981; 22: 2485-7.

18 Pardridge WM, Sakiyama R, Fierer G. Transport of propranolol and lidocaine through the rat blood-brain barrier. J Clin Invest 1983; 71: 900-8.

19 Moore DC. Systemic toxicity of local anesthetic drugs. Seminars in Anesthesia 1983; 2: 62-75.

\section{Résumé}

Avec l'utilisation d'un nouvel appareil conçu pour ultrafiltration et une technique enzymatique d'immunoassay, les auteurs ont déterminé les effets du $\mathrm{CO}_{2}$ sur la liaison fractionnelle de la lidocaïne aux protéines plasmatiques humaines. Des échantillons identiques de sérum dे des doses thérapeutiques $\left(2.2 \mu \mathrm{g} \cdot \mathrm{mi}^{-1}\right)$ et toxiques $\left(6.8 \mu \mathrm{g} \cdot \mathrm{ml}^{-1}\right)$ de lidocaïne ont été étudiés par tonométrie d $37^{\circ} \mathrm{C}$ pour des $\mathrm{pCO}_{2}$ variant de 0.13 a $10.7 \mathrm{kPa}$ ( 1.0 a $80.5 \mathrm{mmHg}$ ). La fraction de lidocaïne non liée a augmenté d' une façon linéaire avec l'augmentation de la $p \mathrm{CO}_{2}(r=0.93, p<0.001)$. Ces changements aident d̀ expliquer l' augmentation de la toxicité de la lidocaïne sur le système nerveux central quand elle est associée à l'hypercarbie. 